\title{
NEW RECORD OF BACOPA EGENSIS \\ (PLANTAGINACEAE) FOR THE FLORA OF MEXICO
}

\section{Daniel Gonzalez-Socoloske}

Dept. of Biology

Andrews University

Berrien Springs, Michigan 49104, U.S.A.

gonzalezd@andrews.edu

\section{Nelly del Carmen Jiménez Pérez}

\author{
Herbario UJAT \\ División Académica de Ciencias Biológicas \\ Universidad Juárez Autónoma de Tabasco \\ Villahermosa, Tabasco, 86150, MEXICO
}

\section{Nicholas P. Tippery}

\author{
Dept. of Biological Sciences \\ University of Wisconsin-Whitewater \\ 800 W Main St. \\ Whitewater, Wisconsin 53190, U.S.A.
}

\section{Donald H. Les}

Dept. Ecology \& Evolutionary Biology
75 N. Eagleville Rd.
University of Connecticut
Storrs, Connecticut 06269-3043, U.S.A.

ABSTRACT

Bacopa egensis is newly reported for the flora of Mexico and an updated key is provided for the Mexican Bacopa species.

RESUMEN

Bacopa egensis se registra por primera vez para la flora de México con una clave actualizada para las especies mexicanas del género Bacopa.

\section{INTRODUCTION}

Bacopa Aubl. (Plantaginaceae) is a tropical genus of about 60 species, primarily distributed in the Americas, with several species occurring in Africa or having wider distributions (Les 2017; Ahedor 2019). The genus includes wetland plants and several fully aquatic species (Pennell 1935, 1946; Les 2017). Eight Bacopa species currently are known from Mexico, including the submersed aquatic B. reflexa (Benth.) Edwall, which some authors refer to the monotypic genus Benjaminia Mart. ex Benj. (Ahedor \& Elisens 2015; Villaseñor 2016; GBIF 2020). Although not previously reported from Mexico, the aquatic species Bacopa egensis (Poepp.) Pennell is known to occur in North and South America as well as Africa (Hepper 1963; D’Arcy 1979; Barringer \& Burger 2000; Forzza et al. 2010; GBIF 2020).

Originally described from Ega [Tefe], Amazonas, Brazil (Poeppig 1845), B. egensis is native to Central America (Costa Rica, Honduras, Nicaragua), tropical South America (Brazil, Colombia, Ecuador, Peru, Suriname, Venezuela; Barroso 1952; Souza \& Giuletti 2009; Appendix 1), and tropical West Africa (Hepper 1963). Bacopa egensis has been included in floristic treatments of Costa Rica (Barringer \& Burger 2000; Barringer 2015) and Nicaragua (Sutton \& Hampshire 2001), but it is absent from floras of Guatemala (Standley $\&$ Williams 1973) and Panama (D’Arcy 1979, 1987). Bacopa egensis has been regarded as an introduced species in the United States (Ahedor 2019), after first being discovered in Louisiana (Wood 1870; DePoe 1969); however, some authors have indicated that its introduction to North America many have occurred naturally via seeds transported by waterfowl (DePoe 1969; Les 2017). With the exception of records from Arkansas and Louisiana, no records for the species exist north of Honduras (Appendix 1).

In this note we report the first record of B. egensis in Mexico and provide a detailed description of its morphology and habitat. We also present a genetic analysis, which places the species in phylogenetic context with other Bacopa species, and provide an updated key for the genus in Mexico.

\section{MATERIALS AND METHODS}

This species was initially found on $10 \mathrm{Jul} 2011$ by the first author in Laguna Leona Vicario, $11 \mathrm{~km}$ S of Balancán, Tabasco, Mexico during a manatee diet study, which was being conducted in the area (Gonzalez-Socoloske \&

J. Bot. Res. Inst. Texas 14(2): $395-403.2020$

https://doi.org/10.17348/jbrit.v14.i2.1017

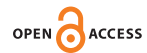


Olivera-Gomez 2019). Voucher specimens were collected on 5 Oct 2018 in Laguna El Cansancio, $10 \mathrm{~km} \mathrm{~S} \mathrm{of}$ Balancán, Tabasco, Mexico $\left(17^{\circ} 42.835^{\prime} \mathrm{N}, 91^{\circ} 33.330^{\prime} \mathrm{W}\right)$ (Gonzalez-Socoloske 382-385) and on 6 Oct 2018 in Laguna Leona Vicario $\left(17^{\circ} 42.886^{\prime} \mathrm{N}, 91^{\circ} 32.868^{\prime} \mathrm{W}\right)$ (Gonzalez-Socoloske 386-393). The water levels in these lakes fluctuate more than $6 \mathrm{~m}$ between high and low water seasons (Gonzalez-Socoloske 2013).

Genomic DNA was extracted for a specimen collected from Laguna El Cansancio, for one nuclear (internal transcribed spacer, ITS) and one plastid ( $n d h F)$ region, following Tippery et al. (2011). DNA regions were amplified and sequenced using the ITS primers ITS5/ITS4 (Baldwin 1992) and the $n d h F$ primers $972 \mathrm{~F}$ and 1603R (Olmstead \& Sweere 1994), using methods described by Tippery et al. (2020). Newly obtained sequences were aligned to those previously deposited in GenBank (Olmstead et al. 2001; Fritsch et al. 2007; Estes \& Small 2008; Kuzmina et al. 2017; Scatigna et al. 2018; Tungphatthong et al. 2018) using the program Mesquite ver. 3.6 (Maddison \& Maddison 2017). We also included an ITS sequence for Conobea scoparioides (Cham. \& Schltdl.) Benth., which Scatigna et al. (2018) found to be nested within Bacopa.

Phylogenetic analyses were conducted on a combined ITS and $n d h F$ data matrix under maximum likelihood using the program IQ-TREE version 2.0.5 (Nguyen et al. 2015) with the TIM3+F+I+G4 model (Posada 2003), and under Bayesian inference using the program BEAST version 1.10.2 (Suchard et al. 2018) with the GTR+I+G4 model. Nodal support values were obtained by running 1,000 rapid bootstrap replicates (maximum likelihood) or by running 10 million generations of Markov Chain Monte Carlo (MCMC), sampling every 1,000 generations, and discarding the first 25\% of trees as burn-in (Bayesian inference). The phylogenetic tree was rooted with Mecardonia procumbens (Mill.) Small, following evidence from Scatigna et al. (2018).

RESULTS

Ecology and habitat.-In Tabasco, Mexico, Bacopa egensis grows along shallow areas (less than $1 \mathrm{~m}$ depth) of the shore in calm sections of freshwater lakes in the lowlands of the Grijalva-Usumacinta River basin (Fig. 1A). Our field observations indicated that it is an annual plant that germinates from a seed bank in the soil. Seasonal variation in water level in these contact lakes can vary as much as $6 \mathrm{~m}$ between the low water season and the high-water season (Gonzalez-Socoloske 2013). Year-long surveys indicate that this species only emerges once the water level begins to rise after the low water season. Depending on the year, this initial rising water phase can occur as early as July and as late as September. The plant flowers, produces fruit and goes to seed, and it eventually disappears during the high-water season, only to return again after the water levels have once again decreased and begin to rise again the following year. This general pattern was also observed in other natant species such as Neptunia prostrata (Lam.) Baill. and Ludwigia helminthorrhiza (Mart.) H. Hara (GonzalezSocoloske 2013)

The portion of the plant that rests on the water surface represents laminae originating from the distalmost 4-5 nodes and a pair of anthetic flowers that extend from the third node down (Fig. 1B). As the plant grows, older laminae and flowers become submerged and the fruiting pedicels become recurved (Fig. 1D). Older laminae begin to disintegrate after being submerged for prolonged periods of time. Plants were only found in a few areas of both lakes, but in the areas they were encountered they were numerous. Other species associated with B. egensis included Eichhornia crassipes (Mart.) Solms and Paspalum repens P.J. Bergius.

Description (based on collections from Mexico). - Plants herbaceous, attached weakly to bottom or free floating. Roots 50-70 mm, white, unbranched, adventitious from lower nodes. Stems glabrous, single or with 1-2 lateral branches from lower nodes, lower stem broader and deteriorating over time, lower internodes 50-70 mm, upper internodes increasingly shortened to $<1 \mathrm{~mm}$ at apex. Leaves opposite, decussate, the lower submersed, deteriorating progressively towards base, the upper (8-10) arising from the distal 4-5 nodes, becoming natant, the congested internodes developing into a flattened floating rosette up to $5 \mathrm{~cm}$ across, leaves spatulate, tapering towards an arcuate base, the laminar portion purplish to green, ovoid, adaxial surface waxy, 10.9-16.7 mm long $\times 12.2-19.3 \mathrm{~mm}$ wide, major veins 5-8, whitish, palmate, each terminating in a large, blunt, tooth, along the distal margin, teeth 10-13 per lamina, the central largest (0.9-1.8 mm), leaf base 


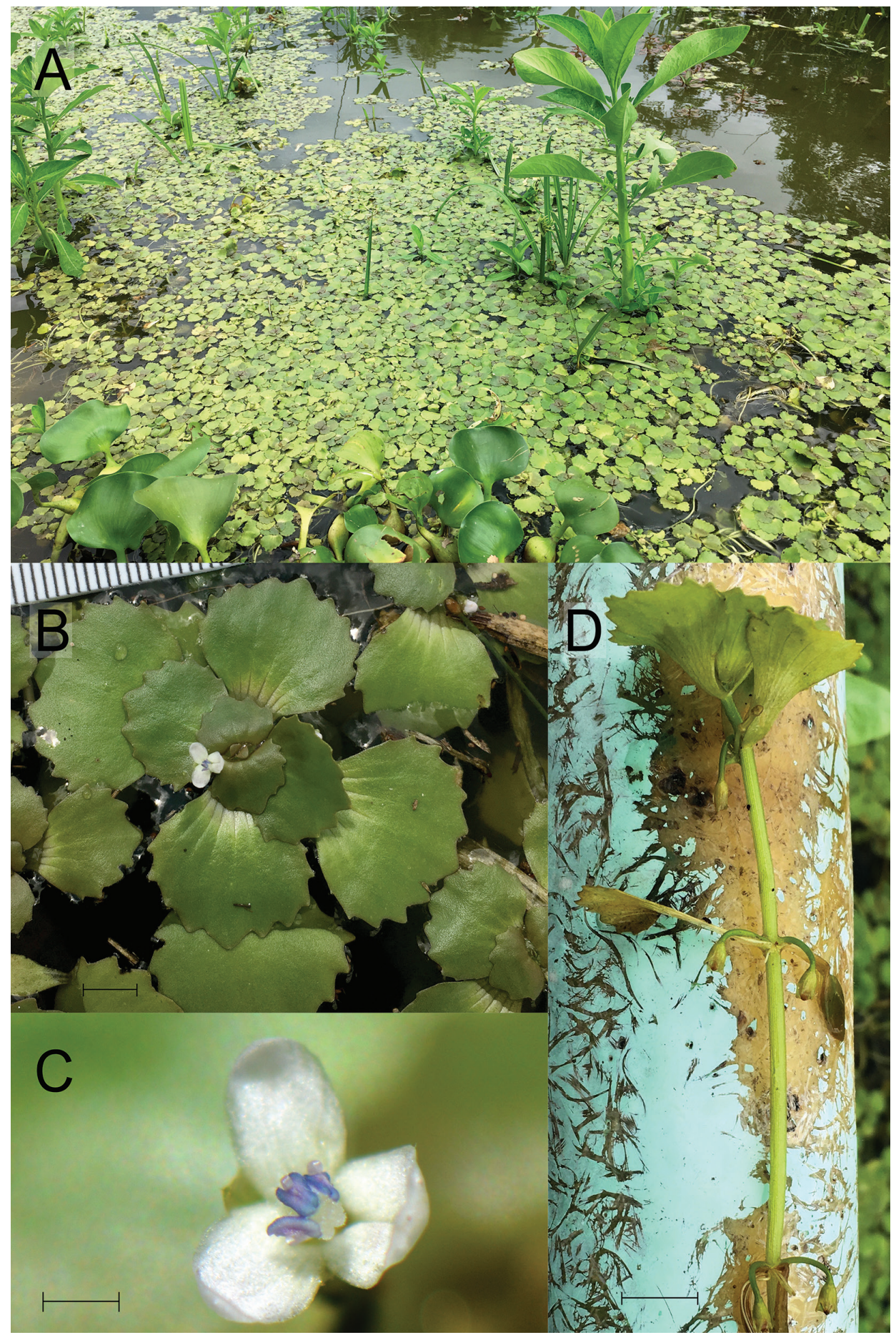

FiG. 1. Bacopa egensis (Poepp.) Pennell in Tabasco, Mexico. A. In natural habitat on the shallow margin of Laguna El Cansancio, Tabasco, Mexico. B.0verview of natant portion of the plant with single open flower. Scale bar $5 \mathrm{~mm}$. C. Closeup of the flower. Scale bar $1 \mathrm{~mm}$. D. Lateral view of the stem and recurved pedicels with the fruit. Note the decomposing lamina in the older nodes that are submerged. Scale bar $10 \mathrm{~mm}$. All photos by Daniel Gonzalez-Socoloske. 
cuneate. Flowers solitary, complete, pedicels erect, 2 [-3] per upper node, sepals 4, 0.7-1.2 mm long, whitishyellow to translucent, connate at base, upper lobes rounded, margins finely ciliate, corolla weakly bilateral, tetramerous but appearing trimerous, petals connate at base, limb of two upper petals oblong, 1.8-1.9 $\mathrm{mm} \times$ $1.2-1.5 \mathrm{~mm}$, white to translucent, dimpled distally, the lower two petals apparently fused medially, appearing as one, collective limb 1.8-1.9 $\mathrm{mm} \times 1.4-1.7 \mathrm{~mm}$, white to translucent, dimpled distally, stamens 3 , the anthers purple, sagittate, $0.5-0.6 \mathrm{~mm}$ long. Fruits capsular, ovoid, 2.4-4.0 $\mathrm{mm}$ long $\times 1.4-3.0 \mathrm{~mm}$ wide, enclosed by persistent calyx, pedicels 5-12 mm long, recurved in fruit, seeds minute, numerous.

Phylogenetic relationships.-Newly obtained DNA sequences were deposited in GenBank under accession numbers MT676828 (ITS) and MT677654 (ndhF). The aligned molecular data matrix consisted of 21 taxa, with a combination of ITS ( 889 characters) and $n d h F$ data (2,119 characters). Ten taxa lacked $n d h F$ data, with many of these represented only by the ITS-1 or ITS-2 spacer. Besides the newly obtained B. egensis sequence, 12 Bacopa species were represented along with Conobea scoparioides. The Bacopa $+C$. scoparioides clade was resolved as monophyletic (Fig. 2). The implied relationship of C. scoparioides with Bacopa species received poor bootstrap support and moderately high posterior probability values. Bacopa egensis was strongly supported as sister to a clade made up of B. eisenii (Kellogg) Pennell from the U.S.A., B. repens (Sw.) Wettst. from Mexico, Central and South America, and B. rotundifolia (Michx.) Wettst., which is found throughout the Americas.

\section{DISCUSSION}

Bacopa egensis has expanded its range to include the U.S.A., where it either was introduced anthropogenically or represents a relatively recent natural introduction (DePoe 1969; Les 2017; Ahedor 2019). Similarly, the populations in Mexico may represent recent range expansions, either natural or anthropogenic. A natural introduction is more likely due to the remote location of the contact lakes and high density of migratory bird species that frequent the area (Gonzalez-Socoloske, pers. obs. 2010-2011). During the low water season and the start of the rising water, large flocks of thousands of black-bellied whistling ducks (Dendrocygna autumnalis) forage in the lakes, and ducks are potential endozoochorous dispersers of Bacopa seeds (Powers et al. 1978). The wellestablished populations of B. egensis and the climatic similarity of southern Mexico with other parts of the species' range all suggest that the populations could persist and potentially expand further in the future. In Africa B. egensis is regarded as native (Hepper 1963), but it is worth noting that some aquatic plants were introduced very early to Africa as weedy associates of cultivated rice (Cook 1985), and thus the genetic similarity between African and American populations of B. egensis merits a more detailed evaluation.

Morphology.-Our specimens closely resemble the descriptions by Poeppig (1845) and DePoe (1969), as well as voucher specimens from both authors (DePoe 6826, Poepigg 2721, Poeppig 2722) and all specimens observed from Louisiana, USA (we examined 24 of the 36 known specimens) and Brazil (we examined 15 specimens from Brazil). We provide a quantitative description of the plant, including the first detailed description of the open flower. Although there is little doubt that they represent the same species, the plants observed in Mexico exhibit some noteworthy differences when compared to published descriptions of B. egensis. For example, DePoe (1969) described white petals with bluish streaks, whereas the plants we observed had entirely white petals. Additionally, our specimens have much smaller corollas $(<2 \mathrm{~mm} \times<2 \mathrm{~mm}$ ) than those reported by DePoe (1969) of 3.5-4.5 mm and subsequently reported by other authors (e.g., Christenhusz 2014). These discrepancies necessitate a closer evaluation of the variation within the species, over all parts of its geographic range. Regardless of variation, the specimens from Mexico are attributable only to B. egensis and, particularly by virtue of their leaf morphology, do not resemble any other accepted species of Bacopa. We thus provide evidence for the inclusion of B. egensis to the Mexican flora and provide evidence for an established population between the known locations in the USA and Central America.

Phylogeny.-Prior molecular phylogenetic studies have supported a clade containing Bacopa and at least one species of the morphologically similar genus Conobea Aubl. (Christenhusz 2014; Scatigna et al. 2018). We recovered the same clade, but with a larger number of Bacopa species represented. Despite the data being available previously for 12 Bacopa species and C. scoparioides, our study is the first to combine these into a 


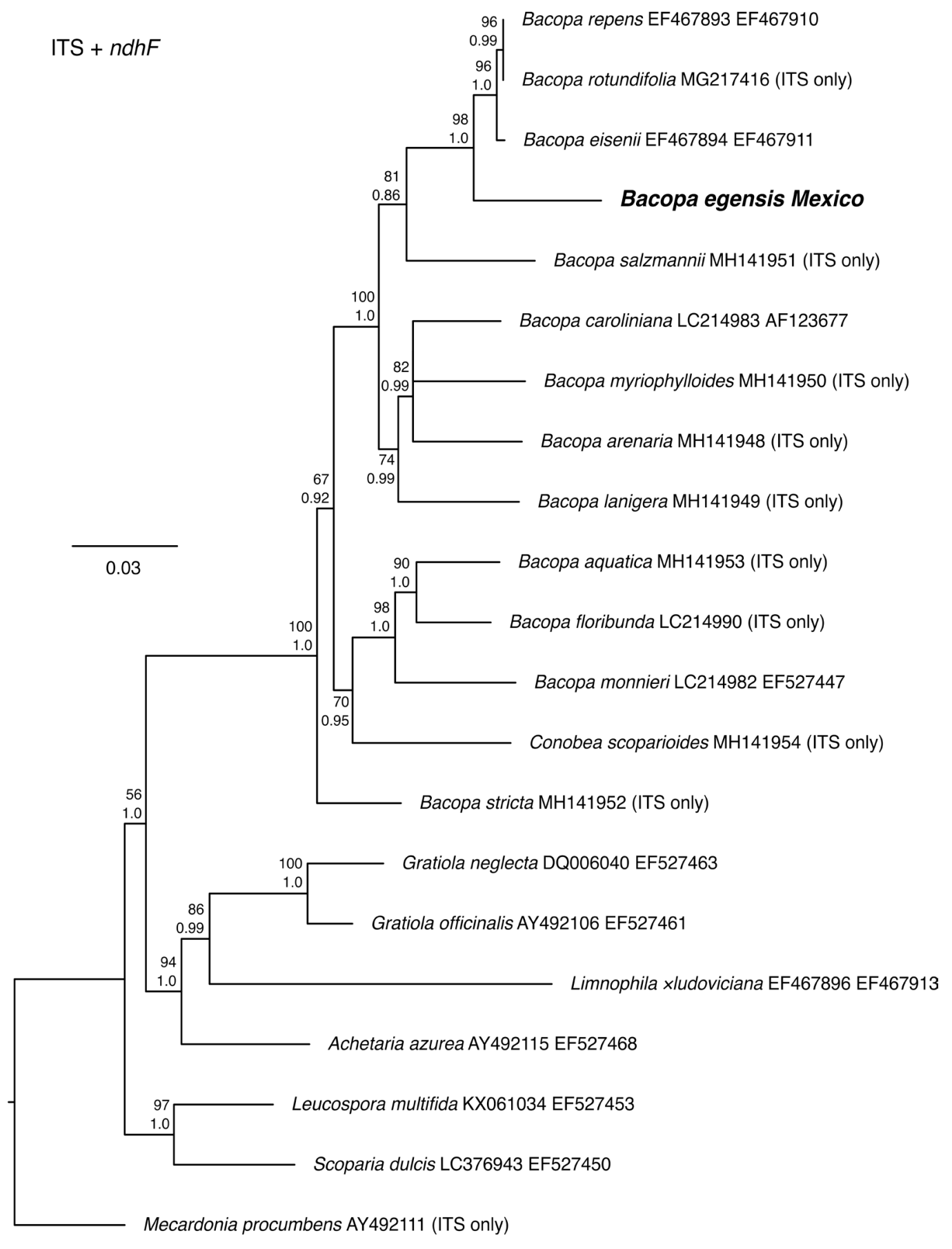

FIG. 2. Molecular phylogeny of Bacopa and related genera, constructed using combined nuclear (ITS) and plastid (ndhF) sequence data. The newly reported specimen of $B$. egensis is shown in boldface. Previously published sequences are shown with their GenBank accession numbers for ITS and $n d h F$, respectively. Nodal values indicate maximum likelihood bootstrap values above and Bayesian posterior probability below. Branch lengths are derived from the maximum likelihood analysis, with a scale bar to indicate substitutions per site. 
comprehensive phylogeny. In our tree (Fig. 2), the widespread B. monnieri resolved in a clade with the eastern hemisphere native B. floribunda (R.Br.) Wettst., as well as B. aquatica Aubl. from the Americas. The remaining Bacopa species in our phylogeny are native only to the Americas, with the exception of B. egensis, which grows also in Africa. The phylogenetic position of $C$. scoparioides, although potentially descended from the same most recent common ancestor as Bacopa species, nonetheless was not resolved with nodal support strong enough to refute the alternative hypothesis that Bacopa and Conobea comprise independent clades. Further taxonomic sampling from Bacopa, Conobea, and related genera may provide a more definitive phylogenetic perspective.

\section{KEY TO SPECIES WITHIN BACOPA IN MEXICO}

1. Plant erect.

2. Stems obscurely quadrangular, glabrous, leaves linear to narrowly oblanceolate, pedicels $<1.5 \mathrm{~mm}$ long, corolla $<4.5$ $\mathrm{mm}$ long

B. sessiliflora (Benth.) Edwall

2. Stems terete, glabrous to faintly pilose, leaves lanceolate, pedicels $1-7 \mathrm{~mm}$ long, corolla $>5 \mathrm{~mm}$ long B. lacertosa Standl.

1. Plants prostrate, floating, or ascendant only distally.

3. Stem entirely glabrous.

4. Bracteoles 2 , leaves $<2 \mathrm{~cm}$ long

B. monnieri (L.) Wettst.

4. Bracteoles absent, leaves $>2 \mathrm{~cm}$ long

B. valerioi Standl. \& L.O. Williams

3. Stems variously pubescent, strigose, villous, or densely hispid, or glabrous only basally.

5. Calyx 4-lobed, the lobes all similar and free only for the distal half of their length

B. egensis (Poepp.) Pennell

5. Calyx 5-lobed, the lobes dissimilar and free almost to the base.

6. Fertile stamens 2

B. repens (Sw.) Wettst.

6. Fertile stamens 4 .

7. Stems and pedicels hispid; leaves entire to finely denticulate, hispid, palmate-veined, corolla tube $>6 \mathrm{~mm}$, style entire

B. salzmannii (Benth.) Edwall

7. Stems and pedicels subglabrous to slightly strigose; leaves entire, glabrous, parallel-veined, corolla tube $<5 \mathrm{~mm}$, style divided

B. rotundifolia (Michx.) Wettst.

\section{CLAVE PARA IDENTIFICACIÓN DE LAS ESPECIES DE BACOPA EN MÉXICO}

1. Hierbas erectas.

2. Tallos obscuramente cuadrangulares, glabros, hojas lineares a estrechamente oblanceolada, pedicelos $<1.5 \mathrm{~mm}$ de largo, corola $<4.5 \mathrm{~mm}$ de largo

B. sessiliflora (Benth.) Edwall

2. Tallos teretes, glabros a escasamente pilosos, hojas lanceoladas, pedicelos de 1-7 mm de largo, corola $>5 \mathrm{~mm}$ de largo

B. lacertosa Standl.

1. Hierbas postradas, flotantes, o ascendentes solo en el ápice.

3. Tallos completamente glabros.

4. Bracteolas 2 , hojas $<2 \mathrm{~cm}$ de largo

B. monnieri (L.) Wettst.

4. Bracteolas ausentes, hojas $>2 \mathrm{~cm}$ de largo

B. valerioi Standl. \& L.O. Williams

3. Tallos variadamente pubescentes, estrigosos, villosos, densamente híspidos o si glabrescentes, solo en las partes basales.

5. Cáliz 4-lobado, lóbulos iguales y libres a la mitad de su longitud

B. egensis (Poepp.) Pennell

5. Cáliz 5-lobado, lóbulos desiguales y libres casi hasta la base.

6. Estambres fértiles 2

B. repens (Sw.) Wettst.

6. Estambres fértiles 4.

7. Tallos y pedicelos híspido-vellosos; margen de las hojas entero a finamente denticulado, lámina híspidovellosa, venación palmada, tubo de la corola $>6 \mathrm{~mm}$, estilo entero

7. Tallos y pedicelos subglabros a ligeramente estrigosos; margen de las hojas entero, láminas glabras, venación paralela, tubo de la corola $<5 \mathrm{~mm}$, estilo furcado

B. rotundifolia (Michx.) Wettst.

Voucher specimens: MEXICO. Tabasco. Municipio Balancán: Laguna El Cansancio $10 \mathrm{~km} \mathrm{~S}$ of Balancán, $17^{\circ} 42.835^{\prime} \mathrm{N}, 91^{\circ} 33.330^{\prime} \mathrm{W}, 5 \mathrm{Oct}$ 2018, Gonzalez-Socoloske 382 (AUB), 383 (UJAT), 384 (F), 385 (UJAT); Laguna Leona Vicario 11 km S of Balancán, $17^{\circ} 42.886^{\circ} \mathrm{N}, 91^{\circ} 32.868^{\prime} \mathrm{W}$, 6 Oct 2018, Gonzalez-Socoloske 386 (UJAT), 387 (AUB), 388 (UJAT), 389 (AUB); Laguna Leona Vicario 11 km S of Balancán, 17²4.107'N, 91³2.531'W, 6 Oct 2018, Gonzalez-Socoloske 390 (UJAT), 391 (F), 392 (UJAT), 393 (AUB).

Bacopa egensis (Poepp.) Pennell, Proc. Acad. Nat. Sci. Philadelphia 98:96. 1946. Hydranthelium egense Poepp., Nov. Gen. Sp. Pl. 3:75, t. 287. 1845. Type: BRAZIL: Crescit in paludibus ad Ega in Brasilia boreali, Octobre lectum, Poeppig 2721 (LECTOTYPE designated here: W0048793, internet image!), Poeppig 2722 (possible ISOLECTOTYPE designated here: GH00078564, internet image!), Illustration of Hydranthelium egense Poepp. in Nov. Gen. Sp. Pl. 3, t. 287 in part (two upper images and drawings 1-10). 1845 (internet image!).

Note.-The lectotypes chosen were based on our consultation with Kanchi Gandhi (GH). Article 9.12 allows for a lectotype to be selected from uncited specimens that comprise the original material, which in this case with specimens collected in Ega, Brazil by Peopigg in 1831-1832, which both 2721 and 2722 match. 
= Hydranthelium crenatum Alph.Wood, Amer. Bot. Fl. 228. 1870. Type: U.S.A. LOUISIANA: Hale s.n. (Lectotype designated here: NY00068534, internet image!; ISOLECTOTYPES designated here: NY00068532, internet image!, NY00068533, internet image!, NY00068535, internet image!).

Taxonomic notes.-The original label of Poeppig 2721 (W) makes reference to the publication describing the species (Poeppig 1845), but indicates t. 286, while the publication references both t. 287 and erroneously t. 286 for the illustration of the species. The confusion might come from the fact that there are two plant species illustrated on t. 287, both Hydranthelium egense and Calceolaria tenella. The reference to C. tenella is correctly indicated as t. 287 both times in the original publication, but the reference to H. egense has t. 287 initially and then t. 286 erroneously when indicating the parts of the illustration (Poeppig 1845). These don't match up with either the species depicted or parts illustrated in t. 286 and therefore the label of Poeppig 2721 (W) should be corrected to indicate t. 287 as the correct illustration. Poeppig $2722(\mathrm{GH})$ is labeled as a duplicate from (W) and although the number is not the same, the location (Ega, Brazil) and the month and year of collection (October 1831) match. Poeppig indicates that the collections were made in October but did not indicate the year (Poeppig 1845), however we know that he made collections in Brazil in 1831-1832 (Brand 1941) so any original material must have been collected by him during those years. We therefore designate the more complete sample, Poeppig 2721 (W), as the lectotype and the much smaller duplicate, Poeppig 2722 (GH), as a possible isolectotype for the species.

Regarding the lectotype of Hydranthelium crenatum, there are four roughly equivalent specimens at NY that were collected by Josiah Hale. A fifth specimen collected in Louisiana but without specified collector or date (NY00068536) also is noteworthy. Among the Hale specimens, one (NY00068534) bears a label printed with "Ex Herbario Alphonso Wood", and this appears to be the most likely candidate for a specimen that would have been consulted by Wood when describing H. crenatum. We thus select this specimen to be the lectotype and the three other Hale specimens (NY00068532, NY00068533, NY00068535) to be isolectotypes.

\title{
APPENDIX 1
}

Herbaria voucher specimens designated as Bacopa egensis or known synonym (*authors observed specimen) from the following herbaria (number of specimens): BR(41), P(16), NY(12), MO(8), K(7), LSU(5), $\operatorname{COL}(3), \operatorname{INPA}(3), \mathrm{GH}(3), \operatorname{TENN}(3), \mathrm{A}(2), \operatorname{ASU}(2), \operatorname{RB}(2), \operatorname{USF}(2)$, $\operatorname{CONN}(2), \operatorname{COLO}(2), \mathrm{NL}(2), \mathrm{W}(1), \operatorname{MEXU}(1), \mathrm{BM}(1), \mathrm{CHSC}(1), \mathrm{US}(1), \mathrm{BM}(1), \mathrm{KANU}(1), \mathrm{UNA}(1), \mathrm{MG}(1), \mathrm{UEC}(1), \mathrm{CGMS}(1)$.

\begin{abstract}
North America (32)
U.S.A. Louisiana: Bruser 308 (LSU00037586), DePoe $6826\left({ }^{*} \mathrm{GH} 01046359,{ }^{*} \mathrm{NY03253794),} \mathrm{Hale} \mathrm{s.n.} \mathrm{[as} \mathrm{Hydranthelium} \mathrm{crenatum} \mathrm{Alph.}\right.$ Wood] (*NY0068532, *NY00068533, *NY00068534, *NY00068535), Reid et al. 5299 (LSU00087534), Thieret 25085(*A01046360), Thomas et al. 2634 (*ASU0118866, *CHSC081823, *NY03253792, LSU00037585), Thomas et al. 11956 (*USF86791, *TENNV0195991), Thomas et al. $11977\left({ }^{*}\right.$ A01046362, CONN00167014, *NY03253793, *NY03253791, LSU00037587), Thomas et al. $33172(*$ ASU0118867, CONN00167015, *GH01046361, *USF115279, *TENNV0195990, *COLO01632058, *COLO01632066, *NY03253790, LSU00037584), Thomas et al. 106842 (*TENNV0195992, KANU202514), s. coll. s.n. [as Hydranthelium crenatum Alph.Wood] (*NY00068536)
\end{abstract}

\section{Latin America (37)}

Brazil: Duarte 6560 (*RB117356), Hopkins 17553 (INPA191795), Hopkins 213 (INPA48512), Moraes et al. 970 (UEC176435), Poeppig 2721 (*W0048793), Poeppig 2722 (*GH00078564), Pott et al. 6271 (CGMS74756), Prance P26629 (*K001139037, *NY01173153, *P05107716), Spruce s.n. ( $\left.{ }^{*} \mathrm{~K} 001139035,{ }^{*} \mathrm{RB} 00381650,{ }^{*} \mathrm{NY} 02699552, \mathrm{MO} 03079898, * \mathrm{P} 03436340, \mathrm{MG} 019750\right)$, Spruce 1127 (*K001139033, *P03436342), Spruce 1230 (*K001139034, *P03436343), Trail 612 (*K001139036). Colombia: Pliego 525 (COL414382), Pliego 407 (COL414383), s. coll. k.255 (*K001139032), Smith 2544 (*NLL.2889113, *NLU.1734399, *P03436341, *P03436344). Ecuador: Spruce 6342 (*K001139031). Nicaragua: Atwood s.n. (MO1697931), Nee \& Robleto Tellez 28147 (MO472111), Herrera Ch. et al. 3888 (MO902646, *MEXU1332131). Peru: Hopkins P17186 (INPA40380A). Suriname: Donselaar 1503 (US2553627). Unspecified location in South America (2): Poeppig s.n. (BM 957905), Pliego 1019 (COL140271)

\footnotetext{
Africa (56)

Cameroon: Letouzey 11369 (*BR0000019039282), Letouzey 1746 (*P03558480), Letouzey 10689 (*P03558477, *P03558482). Central African Republic: Harris 521 (BR0000100039085), Harris 1167 (MO473403, BR0000100039078). Democratic Republic of the Congo: Achten 57B (*BR0000019039329, *BR0000019039336), Achten 57A (*BR0000019039312), Bequaert 7708 (*BR0000019039343, *BR0000019039350), Coûteaux 1004 (*BR0000019039367), Coûteaux 1018 (*BR0000019039374), Demeuse s.n. ( ${ }^{*}$ BR5020184232511), Dewèvre 828 (*BR0000019039473), Dubois 853 (*BR0000019039497), Évrard 6772 (*BR0000019039381), Germain 173 (*BR0000019039480, liquid preserve BR6102003288875), Gillet s.n. (*BR0000019039398), Hens 119 (*BR0000019039435, *P03558484), Jans Edw. 997 $\left({ }^{*} \mathrm{BR} 0000019039442\right)$, Laurent 426 (*BR0000019039503), Lebrun 1466 (*BR0000019039527, *BR0000019039510), Louis 10935 (*BR000001939534, *BR000001939541, *P03558478), Louis 12705 (*BR000001939572, *BR0000019039589, *BR0000019039596), Louis 15790 (*BR000001939602, liquid preserve BR6102006136258), Louis 11389 (*BR000001939558, *BR000001939565, liquid preserve BR6102006499001), Pauwels 851 (*BR0000019039404, *BR0000019039411), Pauwels 4692 (*BR0000019039428), Vanderyst 1730
} 
(*BR0000019039459), Vanderyst $5254\left({ }^{*}\right.$ BR0000019039466), Vermoesen $1247\left({ }^{*}\right.$ BR0000019039305). Gabon: Bidault 4550 (MO101141230), Lachenaud et al. 2028 (MO100769359*BR0000016176270), Lachenaud et al. 2538 (MO100959295), Thollon 4057 (*P03558475), Thollon 947 (*P03558476). Republic of the Congo: Lejoly 96/995 (*BR0000019039299), Sita 1618 (*P03558483). Senegal: Vermoesen 1006 (*BR0000020433963). French Congo: Chevalier 5051 (*P03558479). No locality info (assuming still in Africa): Barter 1252 (*P03558481).

\section{ACKNOWLEDGMENTS}

Funding for travel expenses to collect vouchers was provided by an Andrews University Faculty Research Grant to D. Gonzalez-Socoloske. We thank Barney Lipscomb, Jorge A. Meave, and Socorro González for reviewing an earlier version of the manuscript and providing valuable input. We thank Kanchi N. Gandhi for clarification on type designation. We thank Francisco Pozo and his family for logistical help and assistance in the field in Balancán, Mexico. Special thanks to Cora A. Gonzalez for assistance in the field.

\section{REFERENCES}

Ahedor, A.R. 2019. Bacopa. In: Flora of North America Editorial Committee, eds. Flora of North America North of Mexico, vol. 17. New York, New York, U.S.A.

Ahedor, A.R. \& W. Elisens. 2015. Seed morphology and its taxonomic significance in the subtribe Gratiolinae (Plantaginaceae). Syst. Bot. 40:845-852.

BALDWIN, B.G. 1992. Phylogenetic utility of the internal transcribed spacers of ribosomal DNA in plants: An example from the Compositae. Molec. Phylgen. Evol. 1:3-16.

BARRInGeR, K.A. 2015. Scrophulariaceae. In: B.E. Hammel, M.H. Grayum, C. Herrera, \& N. Zamora, eds. Manual de Plantas de Costa Rica. Vol. VIII. Monogr. Syst. Bot. Missouri Bot. Gard. 131. Missouri Botanical Garden Press, St. Louis, Missouri, U.S.A.

BARRIngeR, K. \& W. Burger. 2000 Scrophulariaceae. In: Burger, W., ed. Flora Costaricensis. Fieldiana, Bot. 41:1-69.

BARROSO, G.M. 1952. Scrophulariaceae: Indígenas e exóticas no Brasil. Rodriguésia 15:9-108.

Brand, D. 1941. A brief history of anthropology in Brazil. New Mexico Anthropologist 5(4): 99-150.

Christenhusz, M.J.M. 2014. Plantaginaceae. In: Flora Mesoamericana, vol. 5. Updated 25 Mar 2014. http://legacy.tropicos. org/Project/FM

Соoк, C.D.K. 1985. Range extensions of aquatic vascular plant species. J. Aquatic PI. Managem. 23: 1-6.

D'ARCY, W.G. 1979. Scrophulariaceae. In: R.E. Woodson \& R.W. Schery. Flora of Panama. Ann. Missouri Bot. Gard. 66:173272. doi:10.2307/2398908

D'ARCY, W.G. 1987. Flora of Panama: Checklist and index. Monographs in Systematic Botany, vol. 17. Braun-Brumfield, Inc., Ann Arbor, Michigan, U.S.A.

DePoE, C.E. 1969. Bacopa egensis (Poeppig) Pennell (Scrophulariaceae) in the United States. Sida 3:313-318.

Estes, D. \& R.L. Small. 2008. Phylogenetic relationships of the monotypic genus Amphianthus (Plantaginaceae tribe Gratioleae) inferred from chloroplast DNA sequences. Syst. Bot. 33:176-182. https://doi.org/10.1600/ 036364408783887375

Forzza, R.C., J.F.A. Baumgratz, C.D.M. Bicudo, A.A. Carvalho, JR, A. Costa, D.P. Costa, M. Hopkins, P.M. Leitman, L.G. Lohmann, L.C. MaiA, \& G. Martinelli. 2010. Catálogo de plantas e fungos do Brasil (Vol. 1, No. 2). Andrea Jakobsson Estúdio: Instituto de Pesquisas Jardim Botânico do Rio de Janeiro.

Fritsch, P.W., F. Almeda, A.B. Martins, B.C. Cruz, \& D. Estes. 2007. Rediscovery and phylogenetic placement of Philcoxia minensis (Plantaginaceae), with a test of carnivory. Proc. Calif. Acad. Sci. 58:447-467.

GBIF (Global Biodiversity Information Facility). 2020. GBIF Occurrence Download (16 June 2020) https://doi. org/10.15468/dl.hw3xkx

Gonzalez-Socoloske, D. 2013. Aspects of the feeding ecology of the Antillean manatee (Trichechus manatus manatus) in the wetlands of Tabasco, Mexico. PhD Dissertation. Duke University, NC, U.S.A.

Gonzalez-Socoloske, D. \& L.D. Olivera-Gomez 2019. Food choice by a free-ranging Antillean manatee (Trichechus manatus manatus) in Tabasco, Mexico. J. Mar. Anim. Ecol. 11:19-32.

Hepper F.N. 1963: Scrophulariaceae. In: J. Hutchinson, J.M. Dalziel, \& F.N. Hepper, eds. Flora of West Tropical Africa, ed. 2, 2:352-374. Crown Agents for Overseas Governments, London, U.K.

Kuzmina, M.L., T.W. Braukmann, A.J. Fazekas, S.W. Graham, S.L. Dewaard, A. Rodrigues, B.A. Bennett, T.A. Dickinson, J.M. Saarela, P.M. CATLIng, \& S.G. Newmaster. 2017. Using herbarium-derived DNAs to assemble a large-scale DNA barcode library for the vascular plants of Canada. Appl. PI. Sci. 5:1700079. https://doi.org/10.3732/apps.1700079 
LES, D.H. 2017. Aquatic dicotyledons of North America: ecology, life history and systematics. CRC Press, Boca Raton, Florida, U.S.A.

MAdDISON, W.P. \& D.R. MAdDISON. 2018. Mesquite: A modular system for evolutionary analysis. Version $3.6 \mathrm{http} / / / \mathrm{mes}-$ quiteproject.org

Nguyen, L.T., H.A. Schmidt, A. Von Haeseler, \& B.Q. Minh. 2015. IQ-TREE: a fast and effective stochastic algorithm for estimating maximum-likelihood phylogenies. Molec. Biol. Evol. 32:268-274.

Olmstead, R.G. \& J.A. Sweere. 1994. Combining data in phylogenetic systematics: an empirical approach using three molecular data sets in the Solanaceae. Syst. Biol. 43:467-481.

Olmstead, R.G., C.W. dePamphilis, A.D. Wolfe, N.D. Young, W.J. Elisens, \& P.A. Reeves. 2001. Disintegration of the Scrophulariaceae. Amer. J. Bot. 88:348-361. https://doi.org/10.2307/2657024

PennelL, F.W. 1935. The Scrophulariaceae of eastern temperate North America. Acad. Nat. Sci. Philadelphia Monogr. $1: 1-650$.

Pennell, F.W. 1946. Reconsideration of the Bacopa-Herpestis problem of the Scrophulariaceae. Proc. Acad. Phil. 98:83-98

PoEPPIG, E. 1845. Nova genera ac species plantarum, quas in regno Chilensi Peruviano et in terra Amazonica: annis MDCCCXXVII ad MDCCCXXXII, vol. 3. Sumptibus F. Hofmeister, Leipzig.

PosADA, D. 2003. Using MODELTEST and PAUP * to select a model of nucleotide substitution. Curr. Protocols 6.5.1-6.5.14. https://doi.org/10.1002/0471250953.bi0605s00

Powers, K.D., R.E. Noble, \& R.H. Chabreck. 1978. Seed distribution by waterfowl in southwestern Louisiana. J. Wildl. Managem. 42:598-605.

Scatigna, A.V., P.W. Fritsch, V.C. Souza, \& A.O. SimÕes. 2018. Phylogenetic relationships and morphological evolution in the carnivorous genus Philcoxia (Plantaginaceae, Gratioleae). Syst. Bot. 43:910-919. https://doi. org/10.1600/036364418X697814

SouzA, V.C. \& A.M. GiuLietTI. 2009. Levantamento das espécies de Scrophulariaceae sensu lato nativas do Brasil. Pesquisas, Botânica 60:7-288.

StAnDLEY, P.C. \& L.O. Williams. 1973. Scrophulariaceae. Flora of Guatemala part IX. Fieldiana, Bot. 24(9):319-416.

Suchard, M.A., Lemey, P., Baele, G., Ayres, D.L., Drummond, A., \& A. Rambaut. 2018. Bayesian phylogenetic and phylodynamic data integration using BEAST 1.10 Virus Evol. 4: vey016. https://doi.org/ 10.1093/ve/vey016

Sutton, D. \& R. HAmpshiRE. 2001. Scrophulariaceae. In: Stevens, W.D., C. Ulloa Ulloa, A. Pool, \& O.M. Montiel, eds. Flora de Nicaragua. Monogr. Syst. Bot. Missouri Bot. Gard. 85. Missouri Botanical Garden Press, St. Louis, Missouri, U.S.A. Pp. 2354-2368.

TIPPERY, N.P., D.H. LES, \& C.R. WilliAms. 2011. Nymphoides humboldtiana (Menyanthaceae) in Uvalde County, Texas - a new record for the U.S.A. J. Bot. Res. Inst. Texas 5:889-890.

TipPeRY, N.P., G.J. BugbeE, \& S.E. SteBbins. 2020. Evidence for a genetically distinct strain of introduced Hydrilla verticillata (Hydrocharitaceae) in North America. J. Aquatic. Plant Managem. 58:1-6.

Tungphatthong, C., J. Somnuek, T. Phadungcharoen, K. Ingkaninan, K., J. Denduangboripant, \& S. Sukrong. 2018. DNA barcoding of species of Bacopa coupled with high-resolution melting analysis. Genome 61:867-877. https://doi.org/10.1139/ gen-2018-0059

VILLASEÑOR, J.L. 2016. Checklist of the native vascular plants of Mexico. Rev. Mex. Biodiv. 87:559-902.

Wood, A. 1870. The American botanist and florist. A.S. Barnes \& Co., New York, U.S.A. 